www.jmscr.igmpublication.org

Impact Factor 5.84

Index Copernicus Value: 71.58

ISSN (e)-2347-176x ISSN (p) 2455-0450

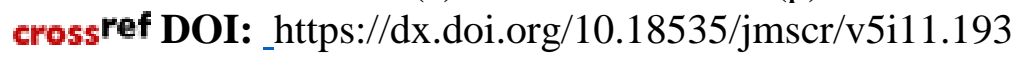

Journal Of Medical Science And Clinical Research

IGM Publication

An Official Publication of IGM Publication

\title{
A Comparative Analysis between Laparoscopic and Open Appendicectomy in A Rural Medical College Hospital
}

\author{
Authors
Dr T.Henry Prabakaran**1, Dr Sendhil Sengodan ${ }^{2}$, Dr S.Senthil Kumar ${ }^{3}$, V.Vaishali ${ }^{4}$ T.Vimal Raj $^{5}$ \\ ${ }^{1}$ Assistant Professor, Department of General Surgery, IRT Perundurai Medical College Hospital \\ ${ }^{2}$ Professor, Department of General Surgery, IRT Perundurai Medical College Hospital \\ Email: sendhilsengodan@gmail.com; Ph.No 9443845814 \\ ${ }^{3}$ Assistant Professor, Department of General Surgery, IRT Perundurai Medical College Hospital \\ Email:dr5347@yahoo.co.in; Ph. No: 9443857777 \\ ${ }^{4,5}$ CRRI, Department of General Surgery, IRT Perundurai Medical College Hospital \\ *Corresponding Author \\ Dr T.Henry Prabakaran MS \\ Assistant Professor, Department of General Surgery, IRT Perundurai Medical College Hospital \\ Email: henryprabakaran@gmail.com,Ph.No 9842793232
}

\begin{abstract}
Background: Appendicectomy is the most commonly performed procedure in emergency \& elective surgery these days. It is done by both open and laparoscopic methods. Previously laparoscopic appendicectomy was performed only in corporate hospitals \& cities. Nowadays it is practised even in rural areas. In this cross-sectional prospective study, we aim to compare both methods of appendicectomy which was performed in a rural Medical College Hospital - IRT Perundurai Medical College \& Hospital. Methods: A cross-sectional prospective study of 88 consecutive patients with the diagnosis of acute appendicitis who underwent laparoscopic $(L A)(n=77)$ and open $(n=11)$ appendectomy $(O A)$ in a period of ten months from OCT 2016 to JULY 2017 was done. A comparative analysis was done between the two groups on the basis of clinical examination, ultrasound findings, operative time, intra-operative findings, pain score, , resumption of normal diet, duration of hospital stay and post-operative complications.

Results: Mean age of patients was 39.5 years in the laparoscopic and 40 years in the open group. Laparoscopic appendicectomy was associated with a lesser incidence of wound infection, shorter hospital stay and earlier return to regular diet \& normal activities. However the operative time depends on the surgeon's experience which is longer compared to open appendicectomy.

Conclusion: The laparoscopic technique is a safe and clinically beneficial operative procedure. It provides certain advantages over open appendectomy, including short hospital stay, decreased requirement of postoperative analgesia, early food tolerance, and earlier return to normal activities. Where feasible, laparoscopy should be undertaken as the initial procedure of choice for most cases of suspected appendicitis.

Keywords: Laparoscopic appendectomy, Open appendicectomy, appendicitis.
\end{abstract}




\section{Introduction}

Appendicitis is one of the most common surgical emergencies requiring appendectomy, with a lifetime risk of approximately 7-8 $\%{ }^{1}$.It requires a comprehensive understanding of its presentation, evaluation, diagnosis, and overall operative management. Approximately $7-10 \%$ of population develop acute appendicitis ${ }^{2}$. Open appendicectomy which was introduced by Mc Burney in 1894 has been the gold standard for treating acute appendicitis for more than a century. ${ }^{3,4}$ The success of laparoscopic cholecystectomy for gall stone diseases gained popularity in almost every surgical speciality. The efficacy of laparoscopic appendicectomy compared to the conventional technique is the subject of debate nowadays 5,6 .Laparoscopic appendectomy has been shown to be feasible and safe in randomized comparisons with open appendectomy. It has improved diagnostic accuracy along with advantages in terms of fewer wound infections, less pain, faster recovery and earlier return to normal activity ${ }^{7}$.In contrast, it consumes more operating time and is associated with increased hospital $\operatorname{costs}^{8}$.It was previously practised only in cities \& corporate hospitals. Nowadays it is being practised even in rural areas, like our centre, which is situated in a rural set-up. Bearing in mind all these details, we have conducted a prospective study to compare the clinical outcomes of both the procedures.

\section{Materials and Methods}

The comparative study was performed in the Department of General Surgery, IRT Perundurai Medical College, Perundurai from OCT 2016 to JULY 2017. All patients between 10 and 70 years of age admitted through the surgery OPD \& Casualty with a clinical diagnosis of acute appendicitis were included in the study. A brief history was collected. Clinical examination \& diagnostic/ pre-operative work-up was done.

\section{Inclusion Criteria}

1) Patients who were willing to participate in the study.
2) Patients with an established diagnosis of appendicitis

\section{Exclusion Criteria}

1) Those cases with severe medical disease which required intensive care

2) Those cases where laparoscopy was converted to open appendicectomy due to complications during the procedure.

3) Patients diagnosed with other pathological conditions along with appendicitis.

This study was approved by the Ethical Committee of our College and no financial grants were obtained from any organization.

Patients were fully informed about the risks and benefits of both the procedures. The eligible patients were randomized into two different groups, laparoscopic group (LA) and open group $(\mathrm{OA})$, for the surgical procedure. All data was collected in a proforma which was specially designed by a senior surgeon, which included the patient's demographic details, operative findings, USG findings, operative time, pain score, resumption of regular diet, hospital stay and postoperative complications.

Patients were diagnosed on a clinical basis with a history of right lower quadrant pain or periumbilical pain migrating to the right lower quadrant with nausea and/or vomiting, fever of more than $38^{\circ} \mathrm{C}$ and/or Leucocytosis $>10000$ cells $/ \mathrm{ml}^{3}$, right lower quadrant guarding, and tenderness on physical examination. Diagnostic \& Pre-operative work- up was done. Cardiologist/ Pulmonologist/ Gynaecologists opinion was obtained for relevant cases. After the case was declared fit by the Anaesthetist, it was posted for surgery.

\section{Surgical Procedure}

The patients were given general anesthesia/ regional anaesthesia (Bupivacaine) by a consultant anaesthetist. The surgery was performed by a consultant surgeon \& assistant who were experienced enough to perform both standardized open and laparoscopic techniques. 
Veress needle was inserted for establishing pneumoperitoneum $^{9,10}$. A standard $10 \mathrm{~mm}$ umbilical port \& two $5 \mathrm{~mm}$ iliac fossa \& supraumbilical ports were made. Diagnostic laparoscopy was done to inspect all the intraabdominal organs. The mesoappendix was dissected by using electrocautery, and the appendix base was tied and divided between 2 endo-loops with laparoscopic scissors. The specimen was retrieved using an Endobag. Drain was kept when needed.

Open appendectomy was performed through a grid-iron incision/ Mc Burney's incision in the usual manner. The mesoappendix was ligated, and the appendix was divided at the base and removed. All specimens were sent for histopathology. All patients were given a standard peri-operative antibiotic regimen of intravenous $3^{\text {rd }}$ generation cephalosporins and metronidazole.

\section{Postoperative Course}

The patients were not given oral feed until they completely recovered from the anaesthesia. Once bowel sounds were present, patients were allowed to take clear liquids and then switched over to a regular diet when the liquid diet was tolerated and flatus was passed ${ }^{11}$ Patients were discharged when they tolerated a regular diet, were afebrile for 24 hours and had good pain control.

\section{Outcome Parameters}

Clinical outcomes were recorded in a proforma which included pre-operative Ultrasound picture, total operative time, intra-operative findings, pain score, time to resume oral intake, hospital stay \& post-operative complications. A standardized postoperative pain regimen was given to all and included intramuscular diclofenac sodium/ Tramadol. Patients were observed for developing any complications in postoperative period. Patients were discharged once they tolerated oral diet \& pain control.

\section{Follow-up:}

Patients were advised to visit the outpatient clinic once a week for 3 weeks. Sutures were removed within 7-10 days. Biopsy reports were collected and patients were observed for development of any complications like wound infection in the $2^{\text {nd }}$ $\& 3^{\text {rd }}$ week. Patients were told to report any complications and were followed for up to 10 months.

\section{Results}

Out of 88 patients with acute appendicitis, 77 patients underwent laparoscopic appendicectomy and the remaining 11 underwent open procedure. Mean age of patients in this study was 39.5 years in the laparoscopic group and 40 years in the open appendectomy group. No significant demographic differences existed between the two randomized groups in relation to age $\&$ sex.

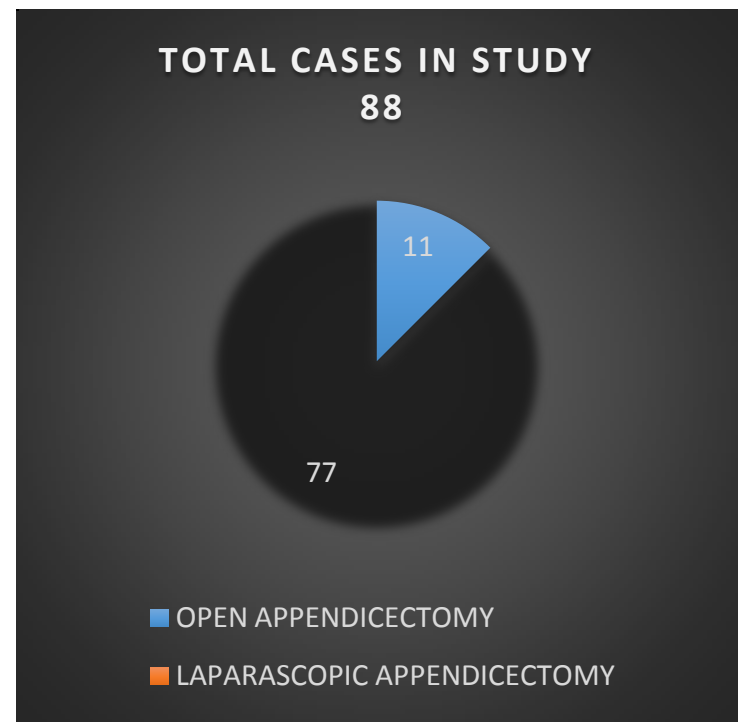

Fig. 1 Total number of cases in the study

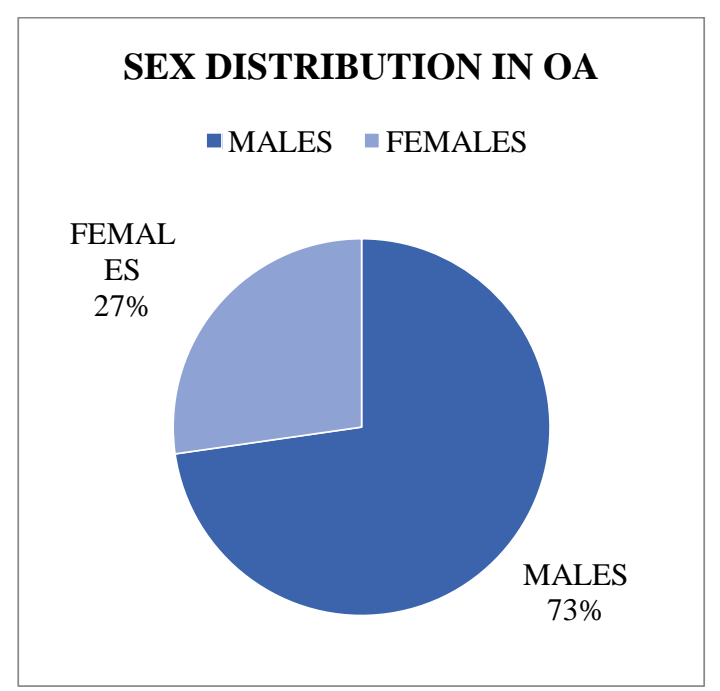

Fig.2 Sex wise distribution of cases in Open appendicectomy 


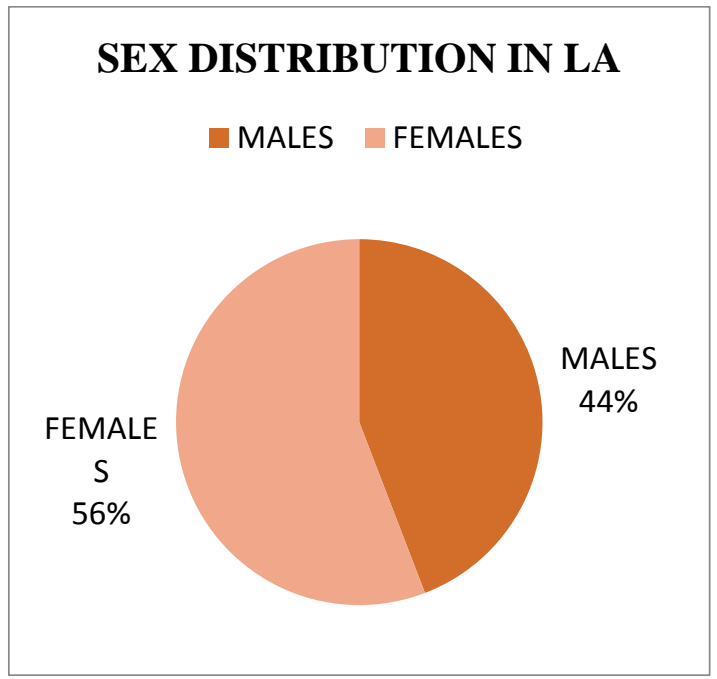

Fig.3 Sex wise distribution of cases in laparoscopic appendicectomy

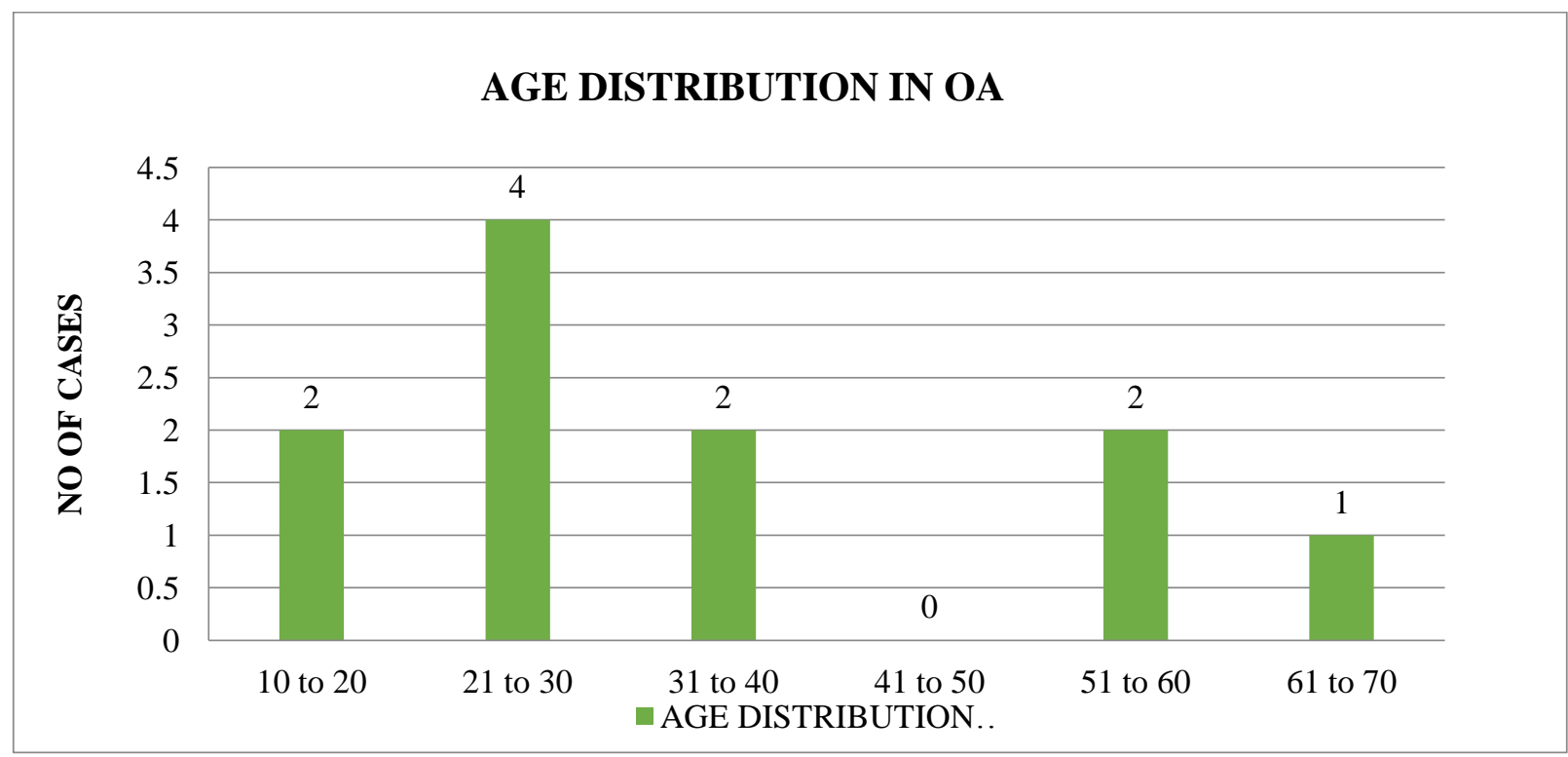

Fig.4 Age wise distribution of cases in open appendicectomy

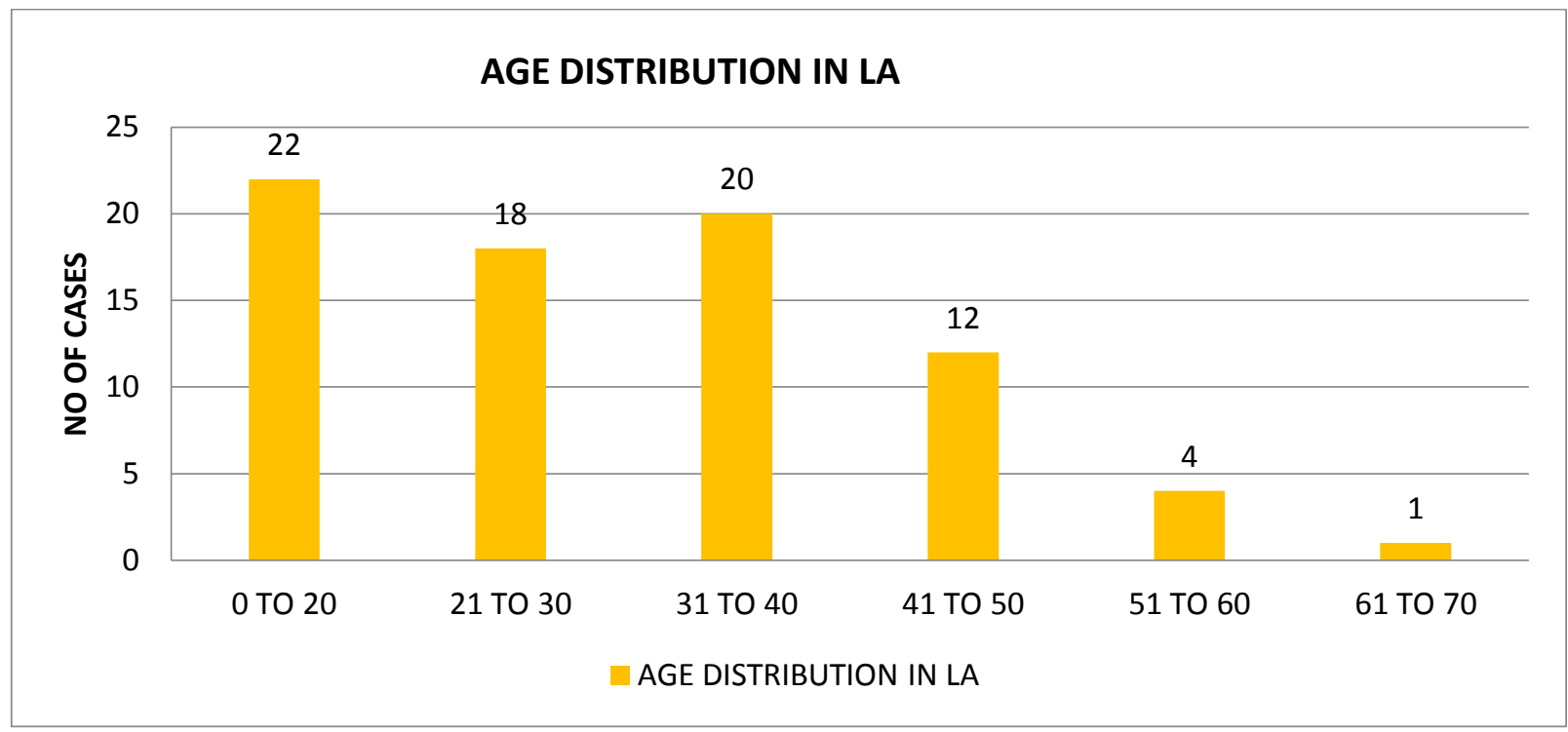

Fig.5 Age wise distribution of cases in laparoscopic appendicectomy 


\section{Emergency/Elective Cases}

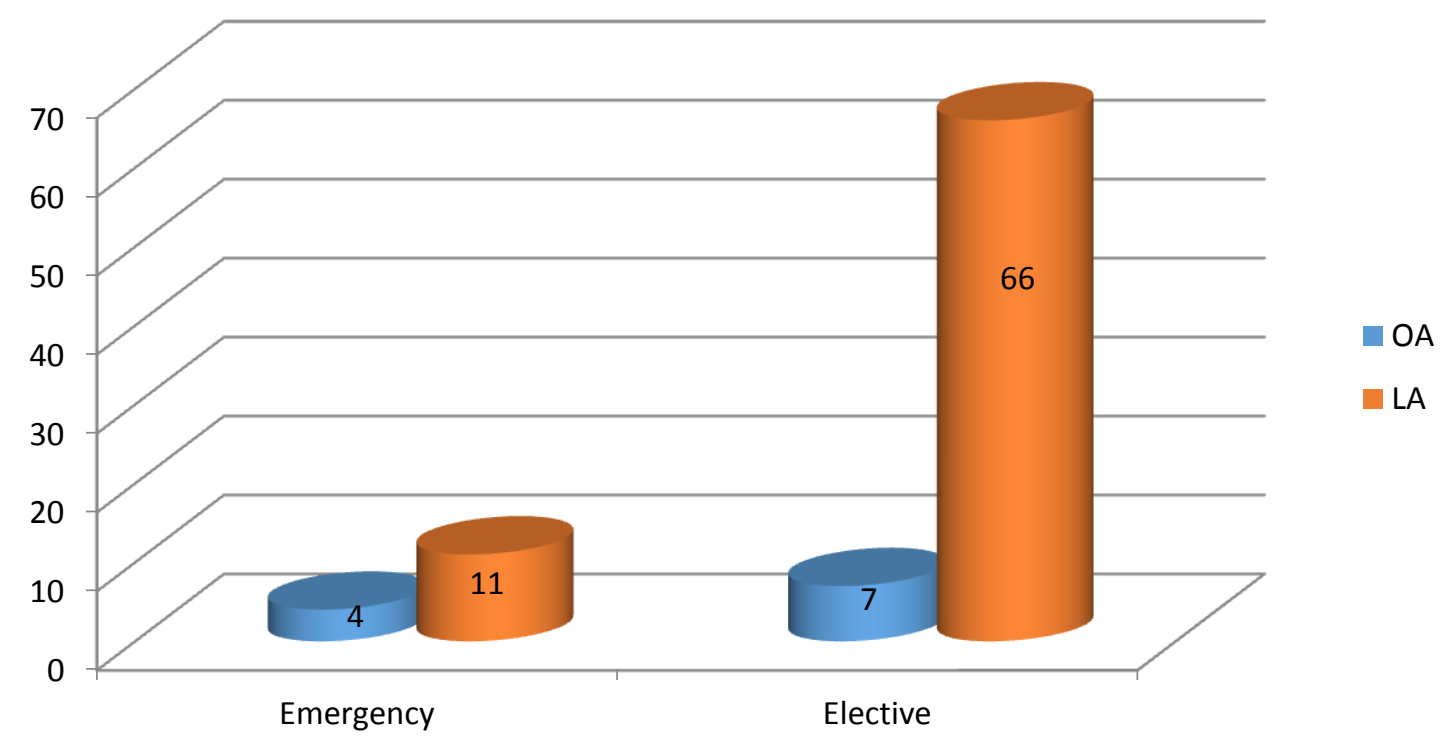

Fig.6 Difference between elective \& emergency surgery in both open \& laparoscopic procedures

\section{Intra-Operative Findings}

Of 88 evaluable cases, Intra-Operative findings revealed acute appendicitis in 49 patients ( OA- 2; LA- 47), Appendicular abscess in 4 patients (OA2; LA-2), Gangrenous appendix in 3 patients (OA3 ; LA- nil), Gangrenous appendix with abscess in 3 patients ( OA-3; LA-nil), Chronic appendicitis in 1 patient (OA-nil; LA-1), \& normal-looking appendix in 28 cases(OA-1; LA-27). There was a slight difference between intra-operative findings and histopathologic findings. Even in normallooking appendix intra-operatively, there were pathological findings of appendicitis in biopsy reports.

Table 1 Intra-operative findings in Laparoscopic/Open appendicectomy

\begin{tabular}{|l|c|c|}
\hline & $\begin{array}{c}\text { Open } \\
\text { Appendicectomy } \\
(\mathrm{n}=11)\end{array}$ & $\begin{array}{c}\text { Laparoscopic } \\
\text { appendicectomy } \\
(\mathrm{n}=77)\end{array}$ \\
\hline $\begin{array}{l}\text { Acute } \\
\text { appendicitis }\end{array}$ & 2 & 47 \\
\hline $\begin{array}{l}\text { Appendicular } \\
\text { abscess }\end{array}$ & 2 & 2 \\
\hline $\begin{array}{l}\text { Gangrenous } \\
\text { appendix }\end{array}$ & 3 & 0 \\
\hline $\begin{array}{l}\text { Gangrenous } \\
\text { appendix with } \\
\text { abscess collection }\end{array}$ & 3 & 1 \\
\hline $\begin{array}{l}\text { Chronic } \\
\text { appendicitis }\end{array}$ & 0 & 27 \\
\hline $\begin{array}{l}\text { Normal-looking } \\
\text { appendix }\end{array}$ & 1 & \\
\hline
\end{tabular}

\section{Operating Time}

In our study, the mean operative time of 95 minutes for the laparoscopic group was longer than the mean operative time of 72 minutes for open appendectomy, and this difference is statistically highly significant.

Table 2 : Difference between the operating time in Open/ Laparoscopic Appendicectomy

\begin{tabular}{|l|c|c|}
\hline $\begin{array}{l}\text { OPERATING } \\
\text { TIME }\end{array}$ & $\begin{array}{c}\text { Open } \\
\text { Appendicectomy }\end{array}$ & $\begin{array}{c}\text { Laparoscopic } \\
\text { Appendicectomy }\end{array}$ \\
\hline Minimum time & $54 \mathrm{mins}$ & $70 \mathrm{mins}$ \\
\hline Maximum time & $90 \mathrm{mins}$ & $120 \mathrm{mins}$ \\
\hline Mean & $72 \mathrm{mins}$ & $95 \mathrm{mins}$ \\
\hline Average time & $74.27 \mathrm{mins}$ & $93.59 \mathrm{mins}$ \\
\hline
\end{tabular}

\section{Pain score}

The pain was relatively less in the laparoscopic group with a mean value of 5.5 when compared to open procedure which had a mean value of 6.5

\section{Oral Intake}

Time taken to tolerate oral intake was significantly less in the laparoscopic group with mean 24 hours compared with a mean of 48 hours in the open group.

\section{Hospital Stay}

Hospital stay was significantly shorter in the laparoscopic group with a mean of 3 days compared with a mean of 7 days for the open group. 
Table 3 Comparison between Open/ Laparoscopic Appendicectomy in aspects of pain score, oral intake \& hospital stay.

\begin{tabular}{|l|c|c|c|c|c|c|c|c|c|}
\hline & \multicolumn{3}{|c|}{ PAIN SCORE } & \multicolumn{3}{c|}{ ORAL INTAKE(hrs) } & \multicolumn{3}{c|}{ HOSPITAL STAY(days) } \\
\hline & MIN & MAX & MEAN & MIN & MAX & MEAN & MIN & MAX & MEAN \\
\hline $\begin{array}{l}\text { OPEN } \\
\text { APPENDICECTOMY }\end{array}$ & 5 & 8 & 6.5 & 24 & 72 & 48 & 5 & 9 & 7 \\
\hline $\begin{array}{l}\text { LAPAROSCOPIC } \\
\text { APPENDICECTOMY }\end{array}$ & 4 & 7 & 5.5 & 12 & 36 & 24 & 2 & 5 & 3 \\
\hline
\end{tabular}

\section{Complications}

In the post-operative period, complications like wound sepsis, vomiting, abdominal distension, fever was more in open surgery than in laparoscopic surgery. In the laparoscopic group only two cases developed complications in the post-operative period, while four cases had complications in the open appendectomy group.

Table 4: Number of complications in Laparoscopic \& open appendicectomy

\begin{tabular}{|l|c|c|}
\hline & $\begin{array}{c}\text { WOUND } \\
\text { SEPSIS }\end{array}$ & $\begin{array}{c}\text { PARALYTIC } \\
\text { ILEUS }\end{array}$ \\
\hline $\begin{array}{l}\text { OPEN } \\
\text { APPENDICECTOMY }\end{array}$ & 3 & 1 \\
\hline $\begin{array}{l}\text { LAPAROSCOPIC } \\
\text { APPENDICECTOMY }\end{array}$ & 2 & 0 \\
\hline
\end{tabular}

\section{Discussion}

Acute appendicitis is one of the most commonly encountered surgical conditions that requires emergency \& elective surgical interventions. Laparoscopic surgery is a major surgical advance in the last two decades. Previously it was performed only in corporate hospitals and major cities. Now it is even performed in rural areas. Meta-analyses have confirmed that laparoscopic appendectomy is safe and results in a faster return to normal activities with fewer wound complications, at the expense of longer operating time.

Because no consensus has been reached, both procedures are still being practiced actively despite randomized trials and meta-analyses. Keeping this in mind, this cross-sectional study was done to compare both the procedures in clinically diagnosed acute appendicitis.

Total operative time in this series was significantly longer in the laparoscopic group (Mean - 95mins) than in the open group (Mean 72 mins), which was measured from the time of first skin incision to the last skin suture applied ${ }^{12}$. Laparoscopic operating time varies slightly according to the experience of the surgeon.

The duration of hospital stay was calculated as the total number of nights spent at the hospital postoperatively. Our study shows a significant short hospital stay in the laparoscopic group (Mean - 3 days) compared with that in the open group (Mean-7days). This is in accordance with other studies which have showed significantly shorter hospital stay ${ }^{13,14,15 .}$

Pain score was comparatively more in the open group with a mean value of 6.5 compared to that in the laparoscopic group with a mean of 5.5. Pain score was assessed using visual analogue scoring ${ }^{16 .}$,

In this study, significantly less time was needed for patients to tolerate oral intake with a mean of 24 hours in the laparoscopic group compared with a mean of 48 hours in the open group. The time taken for bowel to return to normal activity is measured by assessing bowel sounds \& passage of flatus. Previous studies have also shown similar results for the time taken for bowel sounds to return. $^{17}$

Laparoscopic appendectomy has a lower incidence of complications compared with open appendectomy. In our study, the number of cases which developed complications in the postoperative period in the laparoscopic group is only two, whereas in the open group four patients developed complications which included wound sepsis \& paralytic ileus. Wound infection is defined as the presence of purulent or seropurulent discharge from the incision site. Paralytic ileus is defined as the failure of bowel sounds to return within 12 hrs post-operatively.

Wound infections may not be a serious complication but cause a major inconvenience to 
the patient, \& affect his/her quality of life. Laparoscopic surgery is associated with better preservation of the immune system than open surgery. This results in a decreased incidence of infectious complications. ${ }^{17,18,}$

It is encouraging to find that our conclusions are supported by other very recent studies in which laparoscopic appendectomy was performed on another subset of patients ${ }^{19,20}$.These studies have concluded that laparoscopy should be the first choice for any abdominal emergency like appendicitis.

\section{Conclusion}

Our study which was done in a rural set-up, has demonstrated that laparoscopic appendectomy is a safe and clinically beneficial operative procedure over open appendicectomy, in aspects of shorter hospital stay, decreased need for postoperative analgesia, early food tolerance, and earlier return to normal activities inspite of the marginally increased operative time. So Wherever feasible, laparoscopy should be undertaken as the initial procedure of choice for most cases of suspected appendicitis.

\section{References}

1. Michele Pisano,. Luca Ansaloni, in Microbiology for surgical infections, book Edition 2014.

2. Christine Hsu, Stephen john ferzoco, in encyclopedia of gastroenterology, book, Edition 2004.

3. Ukai T, Shikata $\mathrm{S}$, Takeda $\mathrm{H}$ et al. Evidence of surgical outcomes fluctuates over time : from a cumulative metaanalyses of laparoscopic versus open appendecomt for acute appendicitis. BMC gastroenterology 2016; 16:37

4. Taguchi Y, Komatsu S, Sakamato E, et al. Laparoscopic versus open surgery for complicated appendicitis in adults: a randomized controlled trial. Surg Endosc 2016; 30:1705-12.
5. Thomson JE, Kruger D, Jann-Kruger C et al. Laparoscopic versus open surgery for complicated appendicitis: a randomized controlled trial to prove safety. Srg Endosc 2015; 29:2027- 32.

6. Jaschinski T, Mosch C, Eikermann M, et al. Laparoscopic versus open appendicectomy in patients with suspected appendicitis: a systematic review of metaanalyses of randomized controlled trials. BMC Gastroenterol 2016; 16:37.

7. Antonio Biondi, Carla Di Stefano, Francesco Ferrara et al, World Journal of emergency Surgery $2016,11: 44$

8. Hannu lintula, Hannu kokki, kari vanima et all. Arch pediatr adolese med 2004 colon 158(1):34 -37.

9. Vilos GA, et al. J Obstet Gynaecolo Can 2017. Laparoscopic entry : A reiview of techniques, technologies \& complications.

10. Bianchi G et Al. Actas Urol Esp. 2016 Laparoscopic access review- is there a safest entry method?

11. Van Bree Sh, et al. Ann Surg. 2014 Identification of clinical outcome measures for recovery of GI motility in postoperative cases.

12. Kilpatrick CC, Orejuela FJ. Management of acute abdomen in pregnancy. A review. Curr opin obstet Gynaecol. 2008 : 20 (6) : 534-539.

13. Cox MR, Mc Call JL toouli J et al, Prospective randomised comparing of open vs laparascopic appendicectomy in men. World J surg. 1996:20:236-6

14. Temple LK, Litwin DE, Mcleod RS. Meta analysis of laparascopic vs open appendicectomy in patient suspected of having acute appendicitis. Can J surg.1999. 42:377-83.

15. Vallina VL Velasco JM, McCulloch CS . Laparscopic vs conventional appendicectomy. Ann surg 1993;218:685-92

16. Xiaohang Li, Jialin Zhang, Lixuan Sang, et al. Laparascopic vs conventional 
appendicectomy meta analysis of randomised controlled trials.BMC gastro enterology 2010 10-129

17. Katkhouda N, Mason RJ, Towfigh S, Gevorgyan A, Essani R.Laparoscopic versus open appendectomy: a prospective randomized double-blind study. Ann Surg. 2005;242:439-448.

18. Tate JJ, Chung SC, Dawson J, et al. Conventional versus laparoscopic surgery for acute appendicitis. $\mathrm{Br} \mathrm{J}$ Surg. 1993;80:761-764.

19. Heikkinen TJ, Haukipuro K, Hulkko A. Cost-effective appendectomy. Open or laparoscopic? A prospective randomized study. Surg Endosc.1998;12:1204-8

20. Garbutt JM, Soper NJ, Shannon WD, Botero A, Littenberg B. Meta-analysis of randomized controlled trials comparing laparoscopic and open appendectomy. Surg Laparosc Endosc. 1999;9:17-26 .

21. Hellberg A, Rudberg C, Kullman E, et al. Prospective randomized multicentre study of laparoscopic versus open appendicectomy. Br J Surg. 1999;86:48-53.

22. Ortega AE, Hunter JG, Peters JH, Swanstrom LL, Schirmer B.Laparoscopic Appendectomy Study Group. A prospective, randomized comparison of laparoscopic appendectomy with open appendectomy. Am J Surg. 1995;169:208-13

23. Sauerland S, Lefering R, Holthausen U, Neugebauer EA. Laparoscopic vs conventional appendectomy-a meta-analysis of randomised controlled trials. Langenbecks Arch Surg. 1998;383:289-295

24. McCahill LE, Pellegrini CA, Wiggins T, Helton WS. A clinical outcome and cost analysis of laparoscopic versus open appendectomy. Am J Surg.1996;171:533537

25. Tate JJ. Laparoscopic appendicectomy. Br J Surg. 1996;83:1169-70
26. Guller U, Hervey S, Purves H, et al. Laparoscopic versus open appendectomy: outcomes comparison based on a large administrative database. Ann Surg. 2004;239:43-52

27. Pedersen AG, Petersen OB, Wara $P$, Rønning H, Qvist N, Laurberg S.Randomized clinical trial of laparoscopic versus open appendicectomy.Br J Surg. 2001;88:200-205

28. Milewczyk M, Michalik M, Ciesielski M. A prospective, randomized, unicenter study comparing laparoscopic and open treatments of acute appendicitis. Surg Endosc. 2003;17:1023-1028

29. Moberg AC, Berndsen F, Palmquist I, Petersson U, Resch T, Montgomery A. Randomized clinical trial of laparoscopic versus open appendicectomy for confirmed appendicitis. $\mathrm{Br} \quad \mathrm{J}$ Surg. 2005;92:298-304

30. Ignacio RC, Burke R, Spencer D, Bissell C, Dorsainvil C, Lucha PA.Laparoscopic versus open appendectomy: what is the real difference? Results of a prospective randomized double-blinded trial. Surg Endosc.2004;18:334-7

31. Frazee RC, Roberts JW, Symmonds RE, et al. A prospective randomized trial comparing open versus laparoscopic appendectomy.Ann Surg. 1994;219:725-8

32. Yong JL, Law WL, Lo CY, Lam CM. A comparative study of routine laparoscopic versus open appendectomy. JSLS. 2006;10:188-92

33. Marzouk M, Khater M, Elsadek M, Abdelmoghny A. Laparoscopic versus open appendectomy: a prospective comparative study of 227 patients. Surg Endosc. 2003;17:721-724

34. Utpal De. Laparoscopic versus open appendicectomy: An Indian perspective. JMAS. 2005;1:15-20. 